\title{
THE CLINICAL DIAGNOSIS, PROGNOSIS AND TREATMENT OF ANOREXIA NERVOSA
}

By R. W. Emanuel, M.A., D.M., M.R.C.P.

The diagnosis of anorexia nervosa can usually be made from the history and physical findings without the assistance of elaborate investigations. This is no new observation as can be seen from a study of clinical accounts published before the beginning of the present century (Morton, I694; Whytt, I768; Gull, 1868 and 1874; Lasègue, 1873). Recently however, anorexia nervosa has passed out of the sphere of the general physican and has been adopted by the psychiatrist and endocrinologist. This step has provided a new and impressive array of therapeutic measures but leaves the prognosis of the disease unaltered. The treatment of the individual case is no more scientific and often less successful than that practised by Morton.

It is still, however, the practitioner or general physician who first has the opportunity of making the diagnosis and it is with this in view that the present series of 24 cases is presented. The instance of the leading symptoms and physical signs is discussed and compared with the findings of other authors.

\section{The Criteria for the Clinical Diagnosis of Anorexia Nervosa}

The criteria that were required before the diagnosis of anorexia nervosa was accepted were as follows, anorexia or failure to eat, loss of weight, amenorrhoea or oligomenorrhoea and the absence of organic disease.

Psychotic patients, particularly those in institutions, may also develop anorexia, loss of weight and amenorrhoea, but the diagnosis of anorexia nervosa should be avoided in these cases, for the physical symptoms are clearly secondary to a major mental disorder. All such patients have been excluded from the observations made in this paper. There is no doubt however, that patients with anorexia nervosa are mentally abnormal. Their mental symptoms however are those of a neurosis or psychoneurosis. These symptoms alone are rarely responsible for bringing the patient under observation and are never sufficient to warrant certification.
Twenty-four cases of anorexia nervosa were collected from the records of the Middlesex Hospital. All living cases were seen and examined personally. In 10 of these, the disease was still present, symptoms having persisted from 5 to 25 years. A further 9 patients had recovered as judged by the return of normal menstruation. These had been followed for periods varying from one to 13 years after recovery. The remaining 5 cases had died.

The diagnosis was made clinically in all cases and although many were subsequently investigated to determine the activity of various endocrines, the only investigation which played an integral part in the diagnosis was a chest $\mathrm{X}$-ray to exclud the presence of active pulmonary tuberculosiso

\section{Observations and Discussion}

In the present series. 96 per cent. of patients were females. This figure agrees closely with those found by other authors. Less than ro per cent. of all cases recorded occur in males. Patients who develop anorexia nervosa appear to be physically. normal during infancy and childhood. Feeding difficulties during the first year of life which were sufficiently severe to cause a radical change in the routine, such as early weaning, or hospital treatment, occurred in only 26 per cent. of cases which was not significantly higher than might be expected in other children. Rose (1943), however, believed that psychological disturbances associated with feeding difficulties were an important aetiological factor.

Menstruation starts before the age of $14 \frac{1}{2}$ years in 80 per cent. of normal females (Wilson and Sutherland, 1950). In the present series, the menarche occurred before this age in $9 \mathrm{I}$ per cent. of cases. Similar figures were obtained by Rahman et al. (1939), McCullagh and Tupper (1940) and Bartels (1946); these authors found that the periods started between the ages of 12 and $14 \frac{1}{2}$ years in 67,79 and 73 per cent. of cases respectively. Decourt and Michard (1950) noted that menstruation started between the ages of $I 1 \frac{1}{2}$ and 15 years in 91 per cent. of their cases. These 
figures show that puberty occurs at the normal time in people who subsequently develop anorexia nervosa. There is little evidence to support Sheldon's suggestion (1937), that puberty is delayed in a significant number of cases.

A history of mental shock preceding the onset of symptoms was obtained in 46 per cent. of the present series. It is not widely appreciated, however, that voluntary restriction of diet is a frequent aetiological factor; it was a feature of 2 I per cent. of the present series, $5^{8}$ per cent. of the cases reported by Rahman et al. (1939), and in I 5 per cent. of McCullagh and Tupper's cases (1940). Although anorexia was always present, it was surprising how many patients would not admit to this symptom even after direct questioning. Anorexia was denied by 46 per cent. of the present series and by $3 I$ per cent. of Bartels' (1946) cases.

Now that the differential diagnostic points between anorexia nervosa and Simmonds' disease have been established (Ryle, 1936; Bruckner et al., 1938; Van Balen, 1939; McCullagh and Tupper, 1940; Farquharson, 1941 and Escamilla and Lisser, 1942), there is no longer any dispute that anorexia nervosa is a disease of psychological origin. Yet, subsequent organic changes may well occur after the disease is established, as shown by the development of amenorrhoea. The exact stage of the illness at which this symptom occurs has been a subject of controversy. Earlier writers considered that it was a manifestation of undernutrition and consequently occurred later in the natural history of the disease (Lasègue, 1873 ; Moeller, I924). It was recognized, however, that in exceptional cases amenorrhoea might precede other symptoms (Ballet, I907; Comby, I908 and Faber, 1926). After studying 5I cases, Ryle (1936) was convinced that in the majority this symptom appeared before much weight had been lost; in recent years this view has gained further support, (Sheldon, 1937; Decourt, 1946; Decourt and Michard, 1949 and Hubble, 1952). In the present series amenorrhoea occurred before 2 stone of weight had been lost in 78 per cent. of the cases. In these patients therefore it must be considered an early symptom and.not a manifestation of undernutrition. Similar figures were obtained by Decourt and Michard (1950) who found that it was an early symptom in 75 per cent. of cases.

The physical findings in the present series conformed closely to those reported by other writers. Extreme thinness was not always present particularly in the more chronic cases. Sixty-three per cent. of the present series were considered to be emaciated or very thin. This figure is comparable with that of Escamilla and Lisser (1942) who found that 75 per cent. of their cases were emaciated. In the present series, 33 per cent. of the cases were thin but not emaciated and if a typical history of anorexia nervosa had been absent, their appearance alone would not have suggested the diagnosis. One case appeared normal although at the time she was 25 per cent. below her standard weight. Here the diagnosis was made on the history and symptoms and confirmed by laboratory tests, many of which showed similar abnormalities to those found in the more typical cases.

Pubic and axillary hair were normal in amount and distribution in 92 per cent. of cases; a similar figure was obtained by Rahman et al. (1939), while Escamilla and Lisser (1942) reported similar findings in 85 per cent. of cases. In contradistinction to these findings, abnormalities of pubic and axillary hair are the rule in Simmonds' disease and were present in 80 per cent. of Escamilla and Lisser's (1942) series of Ior cases. Ryle (I939) reported that the pubic hair might occasionally be of male distribution in anorexia nervosa, but this was not observed in any cases personally examined.

Abnormal hairiness was found in 29 per cent. of the present series and was seen most often over the back of the trunk and the extensor surface of thes forearms. Similar observations were made byo Ryle (1936) in 23 per cent. and Rahman et al (1939) in 45 per cent. of their cases. This peculiarity is very rare in Simmonds' disease and was encountered only once in $r O I$ cases that were proved pathologically (Escamilla and Lisser, 1942). It occurs in starvation (Curran, 1880). Sheldon (1939) suggested that it might be an attempt on the part of the body to preserve heat. This however, does not seem to be a very likely explanation as in 2 cases of the present series the abnormal hairiness persisted for a number of years after recovery. These patients were last seen $4 \frac{1}{2}$ years and 2 years respectively after the periods had returned and their weight was normal. One case was I03 per cent. and the other 98 per cent. of the standard weight. It seems unlikely in these instances that there was any necessity for continued heat preservation. Unlike the hirsuties seen in adrenal cortical overactivity, in both anorexia nervosa and undernutrition it is associated with a low urinary 17 -ketosteroid excretion (Fraser and Smith, I94I; and Landau et al., 1948). This suggests that it is of different aetiology, but its exact nature remains unknown.

The breasts are normally developed in anorexia nervosa; their preservation even in the presence of severe emaciation is one of the characteristic clinical findings. This may be seen even in fatal cases in which death occurs after severe wasting 
(Stephens, 1895). The breasts were normal in 87 per cent. of the present series. In this respect anorexia nervosa differs from starvation seen in concentration camps where atrophy of the breasts in women was almost universal (Helweg-Larsen et al., 1952). There appears to be no explanation for this selective sparing of the breast tissue in anorexia nervosa.

Cyanosis of the extremities occurred in 25 per cent. of the present series. Bartels (1946) found the same incidence in his cases. This peripheral cyanosis may be severe and associated with pain. In one of the cases a bilateral lumbar sympathectomy had been performed following the diagnosis of Raynaud's disease. Another case has been personally observed where the same sequence of events has occurred. In both these the cyanosis and pain persisted after the operation and severe oedema has developed. The peripheral cyanosis seen in anorexia nervosa is constant, unlike that of Raynaud's disease.

Oedema of the legs is not uncommon and occurred in 29 per cent. of the present series. Escamilla and Lisser (1942) found oedema in 20 per cent. of their cases. Berkman et al. (1947), reported oedema in 68 per cent. of cases, but they included cases where oedema developed during the recovery phase when the patient's food intake had increased.

Nocturia, as a manifestation of abnormal water metabolism, is well recognized in conditions of undernutrition and starvation (McCance et al., I95 I and Helweg-Larsen et al., 1952), but has not previously been recorded in anorexia nervosa. It was found in 39 per cent. of the cases reported here. All these cases had normal plasma proteins and showed delayed water excretion.

The blood pressure is usually low in anorexia nervosa. The systolic pressure was below 100 $\mathrm{mm}$. Hg. in 46 per cent. of the present series, the average readings being systolic 105 and diastolic $69 \mathrm{~mm} . \mathrm{Hg}$. These findings are in accord with previous experience (McCullagh and Tupper, 1940) although Escamilla and Lisser (1942), noted rather lower average values for systolic $(89 \mathrm{~mm}$. $\mathrm{Hg}$.) and diastolic pressure $(59 \mathrm{~mm}$. $\mathrm{Hg}$. $)$.

A bradycardia is not uncommon, 50 per cent. of the present series having a resting pulse at 6 a.m. consistently below 60 per min. A bradycardia of this degree was noted in 53 per cent. by Ryle (1936), in 37 per cent. by McCullagh and Tupper (1940) and in 31 per cent. by Escamilla and Lisser (1942).

There are many features which are common to both anorexia nervosa and starvation. The similarity of the disturbances of water metabolism and the early appearance of amenorrhoea, which is rarely absent in either condition, suggest that the factors which control these symptoms may be similar in the two conditions.

\section{Prognosis}

From the present series, in which 24 cases have been followed up for varying periods between 5 and 25 years, 9 cases ( 38 per cent.) have made a complete recovery and in none of these was there a history of relapse. -A further io cases (4I per cent.) continue to have symptoms and the remaining 5 (2 I per cent.) have died. In 3 of these death appeared to be due to innanition, while in the remaining 2 the later stages were complicated by tuberculosis. Previous authors quoted the mortality in anorexia nervosa to be not more than Io per cent. (Ryle, 1936) and 6 per cent. (Turner quoted by Pardee, 194I). No other figures are available and no mention can be found of the recovery rate, which from the cases studied is a little over one-third in 5 years.

\section{Treatment}

The treatment of anorexia nervosa makes disappointing reading and the multiplicity of agents used is a testimony to their indifferent success. Irrespective of the remedy applied the results are approximately the same: one-third of the cases improve, one-third remain the same and one-third deteriorate. Results of this order can be expected in any psychosomatic disorder assuming the therapy is prescribed and carried out with sufficient enthusiasm.

It is always desirable in cases of anorexia nervosa to separate patients from their home surroundings (Charcot, 1890; Nemiah, 1950) and for treatment to be carried out under adequate supervision, preferably in hospital. Enquiries into the home background usually reveal an unsatisfactory relationship between the patient and parents about which little or nothing can be done. Today, the usual treatment is directed towards reassuring the patient and relatives that all organic disease is absent and then increasing the patient's calory intake with small high calory feeds, which may if necessary, be supplemented by an intragastric drip. In addition to this, a discussion of the patient's 'difficulties' should be undertaken (Weir Mitchell, I885; Ross, 1936); this unfortunately is often carried out by a busy house physician or almoner both of whom are inadequately trained for the task. Nevertheless a surprising number of early cases respond, if only temporarily, to reassurance and an increased calory intake, providing the treatment is properly supervised.

Opinions differ on the value of psychotherapy. Rahman et al. (1939) and Moulton (1942), regarded psychiatric treatment to be of considerable 


\section{Books that enshrine profound thought}

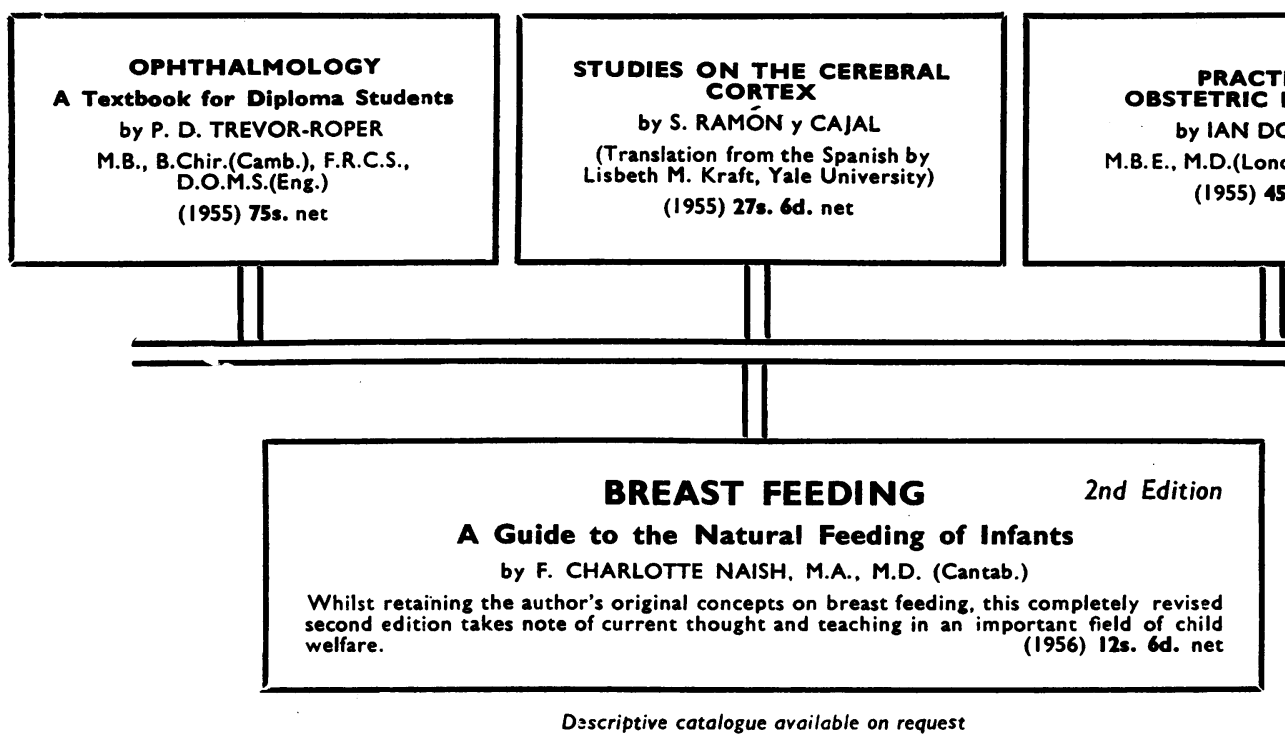

\section{LLOYD-LUKE (medical books) LTD., 49 Newman Street, W.I}

value in cases of anorexia nervosa. Ryle (1936), on the other hand, considered the use of psychoanalytical methods unwise or even harmful. Endocrine therapy has been attempted by many, but results have not been encouraging. The hormone preparations which are most frequently used are insulin (Wilson et al., 1946), thyroid (Berkman, 1930), pituitary extracts (McCullagh and Tupper, 1940), oestrogens (MacGregor, 1936) and ACTH (Greenblatt et al., 195I). There is no good evidence however, that any of these preparations increase the likelihood of therapeutic success.

With the exception of prefrontal leucotomy (Hemphill, 1944; Carmody and Vibber, 1952; Altschule, 1953; Mallinson, I953; Sands, I953), which has now been performed successfully in a number of long standing cases resistant to other forms of treatment, it is doubtful whether we can add very much to Morton's (I694) advice given over 250 years ago. 'Let the patient endeavour to divert and make his mind cheerful by exercise, and the conversation of his friends. For this disease does almost always proceed from sadness and anxious cares. Let him also enjoy the benefit of an open, clear and very good air, which does very much relieve the nerves and spirits.'

\section{Conclusions}

Anorexia nervosa generally develops in young women who are physically normal in infancy and childhood. Puberty occurs at the normal time.

In many cases the disease develops after a mental shock. Voluntary restriction of diet is a significant factor in a proportion of cases.

Amenorrhoea is usually an early symptom and not the result of undernutrition.

The majority of patients are emaciated, but many deny anorexia. Sometimes, however, the loss of weight is less conspicuous and occasionally the physical appearance is normal.

Pubic and axillary hair is generally normal in $\frac{\circ}{3}$ amount and distribution, but abnormal hairiness $\frac{D}{0}$ of the back of the trunk and extensor surface of the forearms is present in a proportion of cases. $\widetilde{N}$

The breasts are generally well developed and N preserved in spite of the wasting of other tissues. N

Cyanosis of the extremities occurs in a proportion of cases and may be severe. The blood pressure is low and bradycardia is common.

Abnormalities of water metabolism are sug- $\stackrel{\mathbb{P}}{\rightarrow}$ gested by the relative frequency of oedema and nocturia.

In 4I per cent. of cases the disease was of more 
than 5 years' duration and the mortality in the present series was 2 I per cent.

\section{Acknowledgments}

I am grateful to the physicians of the Middlesex Hospital for allowing me to study their cases.

This work formed part of a thesis accepted for the degree of D.M. at the University of Oxford.

\section{BIBLIOGRAPHY}

AL'TSCHULE, M. D. (1953), New Engl. F. Med., 248, 808.

BALLET, G. (1907), Med. mod., 18, 255.

BARTELS, E. D. (1946), Acta med. scand., 124, 185.

BERKMAN, J. M. (1930), Amer. F. med. Sci., 180, $4 \mathrm{r}$ r.

BERKMAN, J. M., WEIR, J. F. and KEPLER, E. J. (1947), Gastroenterology, 9, 357 .

BRUCKNER, W. J., WIES, C. H. and LAVIETES, P. H. (I938), Amer. F. med. Sci., 196, 663.

CARMODY, J. T. B. and VIBBER, F. L. (1952), Ann. intern. Med.,

CHARCOT, J. M. (1890), ' Oeuvres Complètes,' Vol. 3, p. 238 , Lecrosnier and Babé, Paris.

COMBY, J. (1908), Arch. Méd. Enf., 11, 562.

CURRAN, w. (1880), Med. Pr., 29, 210.

DECOURT, J. (1946), Paris méd., 36, 249.

DECOURT, J. and MICHARD, J. (1949), Sem. Hôp. Paris, 25, DECOUUR'

Paris, 66, $\mathrm{J}$, and 608 .

ESCAMILLA, R. F. and LISSER, H. (1942), f. clin. Endocrin., 2, 65 .

FABER, K. (1926), Arch. Verdaukr., 37, 17

FARQUHARSON, R. F. (1941), Illinois med. $7 ., 80,193$

FRASER, R. and SMITH, P. H. (194I), Quart. F. Med., N.S.ro, GREENBLATT, R. B., BARFIELD, W. E. and CLARK, S. L. (1951), F. med. Ass. Ga., 40, 299.

GULL, W. W. (1868), Lancet, ii, I $7 \mathrm{I}$.

GULL, W. W. (1874), Trans. clin. Soc. Lond., 7, 22.
HELWEG-LARSEN, P HOFFMEYER, H., KIELER, J., THAYSEN, E. H., THAYSEN, J. H.'THŸGESEN, P. and WULFF, M. H. (I952), Acta med. scand., Vol. 144: sup. 274. HEMPHILI, R. E. (1944), Lancet, ii, 345.

HUBBLE, D. (1952), Ibid., i, I 123

LANDAU, D. R. I., KNOWLTON, K., ANDERSON, D. BRANDT, M.'B. and KENYON, A. T. (1948), 尹́. clin. Endocrin., 8, 133 .

LASEGUE, C. (1873), Arch. gén. Méd., 6 Série, 21, 385.

McCANCE, R. A. et al. (195 I), M.R.C. Special Rep. Series, No. 275, H.M.S.O., London.

McCULLAGH, E. P. and TUPPER, W. R. (r940), Ann. intern. Med., 14, 81 7 .

MacGREGOR, T. N. (1936), Trans. Edinb. obstet. Soc., 56, 153. MALLINSON, P. (1953), Proc. $R$. Soc. Med., 46, 674.

MITCHELL, S. W. ( 1885 ), 'Lectures on diseases of the nervous system especially in women,' Chapter 15, Henry C. Lea, Philadelphia.

MOELLER, E. (1924), Ann. Méd., 16, 45 I.

MORTON, R. (I694), 'Phthisiologia, or a treatise of consumptions,' p.4, S. Smith and B. Walford, London.

MOLIL'TON, R. (1942), Psychosom. Med., 4, 62.

NEMIAH, J.' C. (1950), Medicine, Baltimore, 29, 225

PARDEE, I. (I94I), Med. Clin. N. Amer., 25, 755.

RAHMAN, L., RICHARDSON, H. B. and RIPLEY, H. S. (1939, Psychosom. Med., I, 335.

RICHÄRDSON, H. B. (1939), Arch. intern. Med., 63, I

ROSE, J. A. (1943), Psychosom. Med., 5, 117.

ROSS, T. A. (1936), 'An enquiry into prognosis in the neuroses,' p. 83, University Press, Cambridge.

RYLE, J. A. (1936), Lancet, ii, 893.

RYLE, J. A. (1939), Proc. $R$. Soc. Med., 32, 735

SANDS, D. E. (1953), Ibid., 46, 674.

SHELDON, J. H. (1937), Lancet, i, 360 .

SHELDON, J. H. (1939), Proc. R. Soc. Med., 32, 738.

STEPHENS, L. (1895), Lancet, $i, 31$

TURNER, R. H. (1938), ' Unpublished communication to American Association of Physicians at Atlantic City 1938,' Quoted by PARDEE, (I94I).

VAN BALEN, G. F. (1939), Acta. med. scand., ror, 433.

WHYTT, R.' (1768), 'The works of Robert Whytt,' p. 598, 'T

Becket and P. A. De Hondt, Edinburgh. W. M. (1946), Sth. med. ₹., Bgham, Ala., 39, 408 .

WILSON, D. C. and SUTHERI.AND, I. (I950), Brit. med. 7 ., ii, 862.

Bibliography continued from page 237-C. C. Burt, B.Sc., M.B., Ch.B.

\section{BIBLIOGRAPHY}

ALLEN, E. V., BARKER, N. W., and HINES, E. A. (I948), 'Peripheral' Vascular Diseases,' W. B. Saunders Company, Philadelphia and London.

ALLEN, E. V., BARKER, N. W., and HINES, E. A. (1955), 'Peripheral Vascular Diseases,' 2nd ed., W. B. Saunders Company, Philadelphia and London.

BARKER, N. W. (1931), F. Amer. med. Ass., 97, 84I.

BOYD, A. M., RATCLIFFE, A. H., JEPSON, R. P., and JAMES, G. W. H.'(1949), Ұ. Bone $\mathscr{f}$ t. Surg., 31B, 325 .

BUERGER, L. (1908), Amer. F. med. Sci., 136, 567.

BUERGER, L. (1917), Ibid., 154, 3 19.

BUERGER, L. (1924), "The Circulatory Disturbances of the Extremities,' W. B. Saunders Company, Philadelphia and London.

BUERGER, L. (1929), Arch. Path., 7, 38 I.

BURT, C. C. (1954), Edinb. med. F., 61, 273.

BURT, C. C. (1955), 'Long-term Out-patient Anticoagulant Therapy.' 'In 'Thrombosis and Embolism,' Benno Schwabe $\&$ Co., Basel.

GINSBURG, N. (1917), Amer. F. med. Sci., 154, 328.

HORTON, B. T., and DORSEY, A. H. E. (1932), Arch. Path. I3, 190 .

INGRAM, G. I. C. (1955), 'Laboratory Studies in Migratory' Phlebitis.' 'In Thrombosis and Embolism,' Benno Schwabe \& Co., Basel.

KINMONTH, J. B. (1948), Lancet, ii, 717.

LEARMONTH, SIR JAMES (1952), "The Clinical Study' of Patients with Chronic Obliterative Arterial Disease.' In the Proceedings of the First Congress of the European Society of Cardiovascular Surgery, Strasbourg.

LEARMONTH, J. R., BLACKWOOD, W., and RICHARDS, R. L. (1944), Edinb. med. F., 51, I.

LINDBOM, A. (1950), Acta radiol., Suppl. 80.

LYNN, R. B., and BURT, C. C. (I949), Edinb. med. F., 56, 422.
McGRATH, E. J. G. (1935), Arch. intern. Med., 55, 942.

MADDOCK, W. G., MALCOLM, R. L., and COLLIER, F. A. (1936), Amer. Heart f., 12, 46.

MAVOR, G. E. (1955), Quart. F. Med., 24, 229.

MAZANEK, J. (1949), Brit. med. F., ii, 935.

MEYER, W. (1916), Ann. Surg., 63, 280.

MEYER, W. (I918), Э. Amer. med. Ass., 71, 268.

MICHELS, E., and PARKES WEBER, F. (1903), Brit. med. Ұ., ii, 566.

NAIDE, M. (1941), Amer. F. med. Sci., 202, 822.

RABINOWITZ, H. M. (1923), Surg. Gynec. Obstet., 37, 353.

RICHARDS, R. L. (1953), Brit. med. F., i, 478.

ROTH, G. M., MACLAY, E. V,. and ALLEN, E. J. (1938), Arch. intern. Med., 62, $4 \mathrm{I} 3$.

SAMUELS, S. S. (1936), 'Diagnusis and Treatment of Diseases of Peripheral Arteries,' p. 260, New York University Press.

SHEPHERD, J. T. (195 I), Brit. med. F., ii, 1007.

SILBERT, S. (1935), Surg. Gynec. Obstet., 61, 214.

SULZBERGER, M. B. (1934), F. Amer. med. Ass., ro2, I I.

DE TAKATS, G. (1943), Surg. Gynec. Obstet., 77, 31 .

TELFORD, E. D., and STOPFORD, J. S. (1935), Brit. med. F., i, 863 .

'THEIS, F. V., and FREELAND, M. R. (1939), Arch. Surg., 38. ז9 I. THOMSON, K. W. (r 94 I), New int. Clin., 4, 2 , 156.

TROUSSEAU, A. (I 868), 'Lectures on Clinical Medicine' delivered at the Hôtel Dieu de Paris, Trans. I868, New Sydenham Society, London.

WESTCOTT, F. H., and WRIGHT, I. S. (1938), f. Allergy, 9, 555. WILSON, G. M. (1950), M.D. Thesis, Edinburgh University, Vol. I, p. 77.

WRIGHT, I. S., an 1 MOFFAT, D. (1934), f. Amer. med. Ass., I03 318. 